\begin{tabular}{l}
\hline 臨 床 \\
\hline
\end{tabular}

日常臨床における側頭骨断層撮影

$$
\text { ルーチン化の試み }
$$

新川敦*。松川 純一。坂本裕

本村 美雄**。新貝友三郎***

\title{
A New Attempt at Standadization of Temporal Bone Tomography
}

\author{
Atsushi Shinkawa,* Junichi Matsukawa, Yutaka Sakamoto, \\ Yoshio Honmura,** Tomosaburo Shingai*** \\ *(Tokai Univ.) **,***(Kawasaki City Hosp.)
}

The introduction of the operation microscope and the progress of the hearing test apparatus into otology drastically altered the performance of tympanoplastic operations. The lack of application of the diagnostic aid sometimes forces the otologist to perform exploratory operations, as the conventional roentgens of the temporal bone, which usually provide information concerning the cholesteatoma, only pneumatization of the mastoid cells and inflammatory changes, ràrely reveal pathologic conditions in or near the ossicles.

Thus we prefer the tomographic examination as a routine method. According to our experience with about 250 cases of ear tomography, posteroanterior projection of the temporal bone proved to be the most suitable for demonstration of the ossicles. We used Princeps 60 type tomographic apparatus with the use of the plesiosectional casette, which involved five sets of matched intensifying screens. On our Princeps 60 tomography, the tube-film distance is $85 \mathrm{~cm}$. and the extent of the tube is $30^{\circ}$. The resultant film gives excellent visualization of anatomic details such as the ossicles, radiologic spur, cochlea, lateral semicircular canal, internal meatus, etc. In the preoperative tomographic examination, we added a lateral projection using a polytomographic apparatus, Toshiba $\mathrm{C}$ type.

\section{I 。緒言}

日常臨床における耳疾患を診断する際，特に鼓室形成術の進歩，普及に伴ない術前に病巣所見， 特に上鼓室，耳小骨の状態をできるだけ詳細，正確に把握する事は，手術適応の決定等に関して極

\footnotetext{
*東海大学矣学部耳鼻咽喚科学教室

**川崎市立川崎病院耳鼻咽喉科

***同理学診療科
} 
めて望ましいことであり，そのためには鼓膜所見，聴力検査， X 線検査がいずれあ必要不可欠であ る。しかし microscope の導入，聴力検査法の進歩と比較した場合，X線検査に関する進歩はい まだ足踏み状態といわざるを得ないであろう。特にそのルーチン撮影は, Schuller, Sonnenkalp, Mayer, Stenvers などの古典的な方法に頼っているのが現状である.

耳小骨を中心として上鼓室，乳突洞の状態，奇形，変位の有無などを術前にできるだけ把握する ことは，鼓室形成術の適応決定，術式の決定，手術事故防止などの面から，極めて望ましいことで ある。

耳小骨を主たる目的とした単純撮影法は, 主としてフランスで試みられ，1939年 Chausse III 法 ${ }^{1)}$ が，1955年 Guillen 法2) (一側経眼窩法) が報告されている。他に Samuel ${ }^{3)}$, Welin ${ }^{4)}$,

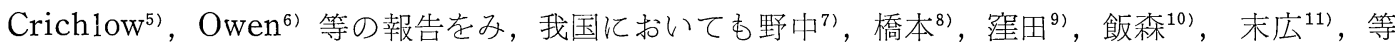
数多くの先生達により研究，報告されているが，いずれにおいても側頭骨は骨密度が高く，加微 細にして複雑な構造をむつために，いかなる単純撮影法においても重影が避けがたく，読影を難し くしている.

我々も種々の単純撮影法, 特に Guillen 法, Chausse III 法を試みたが, 必ずしも毎回情報量 の多い写真が得られるとは限らず，再現性がないため，ルーチン検査としてのGuillen 法, Chausse III 法は断念せざるを得なかった。そてで我々はルーチン検査として断層撮影の導入を考えた が，技術者の手間がかかるとと，患者の被曝線量，負担等の問題から初期にはかなりの抵抗があっ た。しかしながら屍体頭部を用い, 各種断層撮影装置を使用して断層面, 断層角度, 位置決め, 被 曝線量測定などの基礎的研究に加え，約 250 例の症例を対象とした臨床的検討を加えた結果，先に 述べた様なルーチン撮影としての諸条件をほぼ解決し，技術的にも安定してほとんど失敗がなく， 毎回情報量の多い写真が得られるようになったため，その臨床的価值に注目している。今回は我々 の行っている側頭骨ルーチン断層撮影法の概略を示すと共に, 若干の考按を加えたので諸兄の御批 判をあおぎたい。

\section{II. 我々の行っている側頭骨ルーチン断層撮影の概略}

1. 断層撮影装置, 条件について

フランス CGR 社製Princeps 60型（図1） 断層方式: 円孤軌道

断層角度： $0 \sim 70^{\circ}$ 可変であるが $30^{\circ}$ を採用

$$
\text { している. }
$$

管球截断面間距離: $85 \mathrm{~cm}$

拡大率：1.1〜1.5倍まで可変であるが：：1.2 倍を採用している。

絞り：専用長型 Tubus 及び横方向可変特製 絞り（試作品），（図 3 ）。

$\mathrm{X}$ 線発生装置： 3 相インパルス $1000 \mathrm{~mA}$ 組合 わせ

X 線管焦点 : $1 \times 1 \mathrm{~mm}$

多層カセッテ：大日本塗料社製 S T E $5-3$ 型（試作品：3mm間隔 5 層）
撮影条件

管電圧 : 68 K. V. P. 80 K. V.P.

電 流 : $100 \mathrm{~mA}$

時 間: 2.0 秒

距 離: $85 \mathrm{~cm}$

撮影方向

後頭前頭位

2. 位置決めについて本装置は頭部断層専用 に設計されてあるため, 光照射により簡単に位 置決めができる，撮影の体位は座位で頭部は正 しい baseline (OM線)をとる。撮影前に医 師が患者の外耳道孔の上鼓室の中心に該当する 部位に，マジックインクで印をつける。乙れは 図 4 の如く外耳道孔之鼓膜の位置関係に個人差 があり，乙の処置により断層面をできるだけ正 


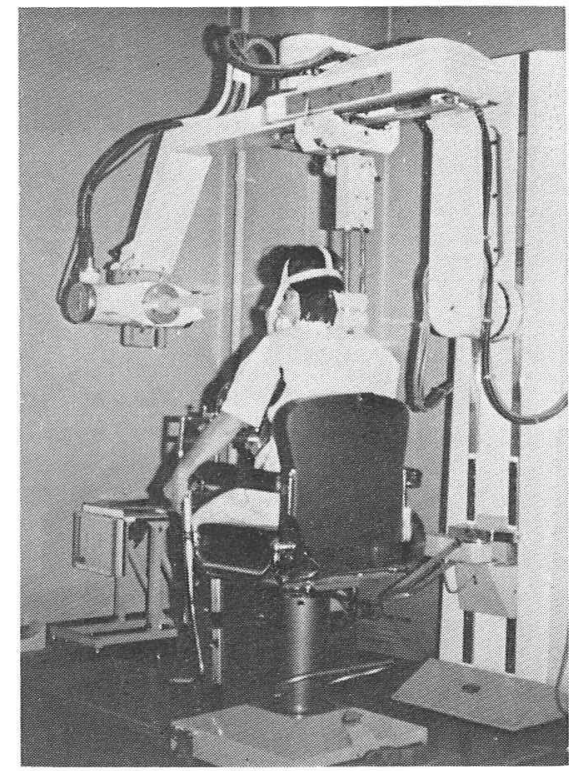

図 I C GR 社製 Princeps 60型

確に目的とする部位（上鼓空の中心）に近づけ ることが可能である。との印に本装置の側面光 照射を左右それぞれ合わせるととにより，簡単 に位置決めができる。

3. 影像について

図 5，6は本装置により得られる影像とその シェーマである。斨層面，個人差により細部

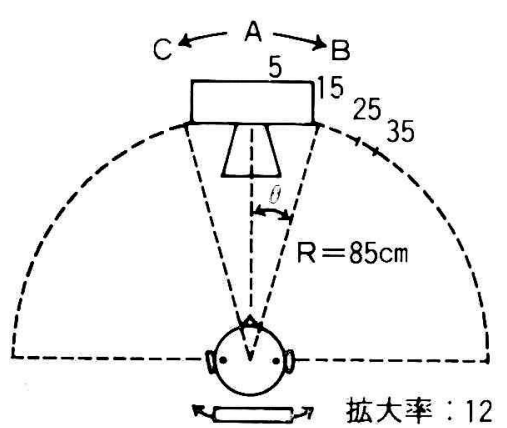

図 2 装置プリンセプス60型（円孤軦道）

は異なるが，側頭骨の前うjのフィルムでは，耳 小骨の malleus, incus が一塊となって写り

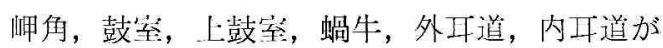
湖暸に写し出される。禹に慢性川耳炎の際に診 断価值の高い上鼓空外侧壁 (radiologic spur) を写し出す事ができる。こ机は従来の占典的単 純撮影法では写し出すととが難しく，その診断 的価値に注目している。後うのフィルムでは耳 小骨は消え, 乳笑洞, 外側半規管, 前半規管: 前庭がはっきりすると共に蝸牛の回転が䕐え。 る。

臨床例 250例における検討ではほほ全例に外 耳道，耳小骨（malleus，incus）, 上鼓室外側
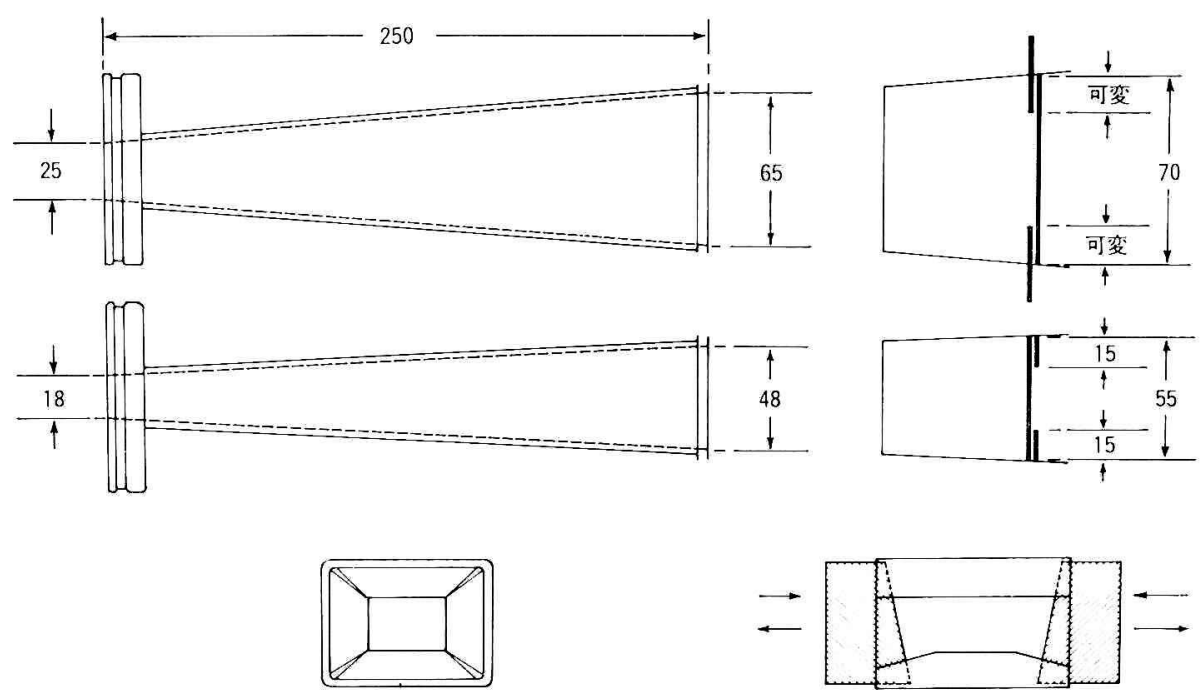

図 3 眐製ツーブスと可变絞り 

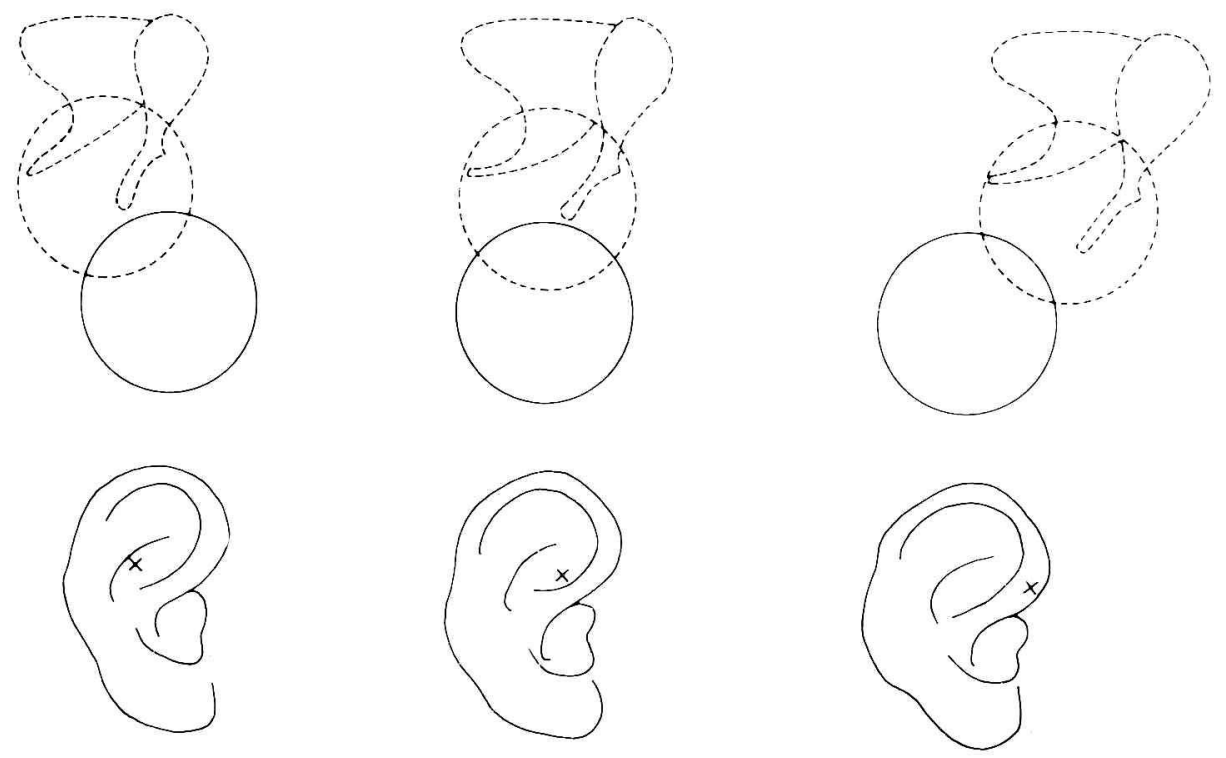

図4 耳介と上鼓室中心の関係
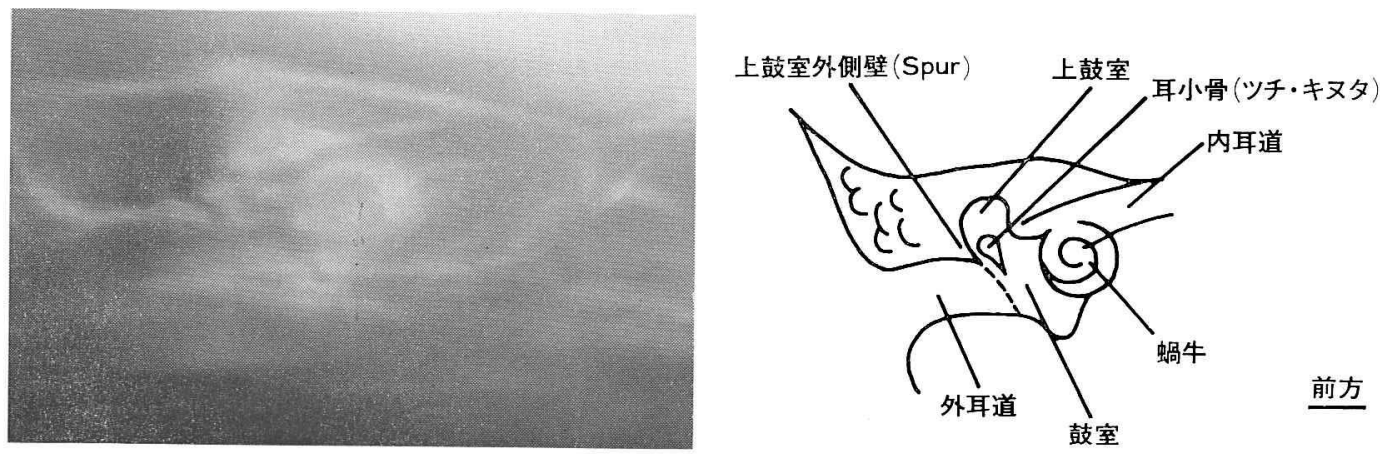

図 5
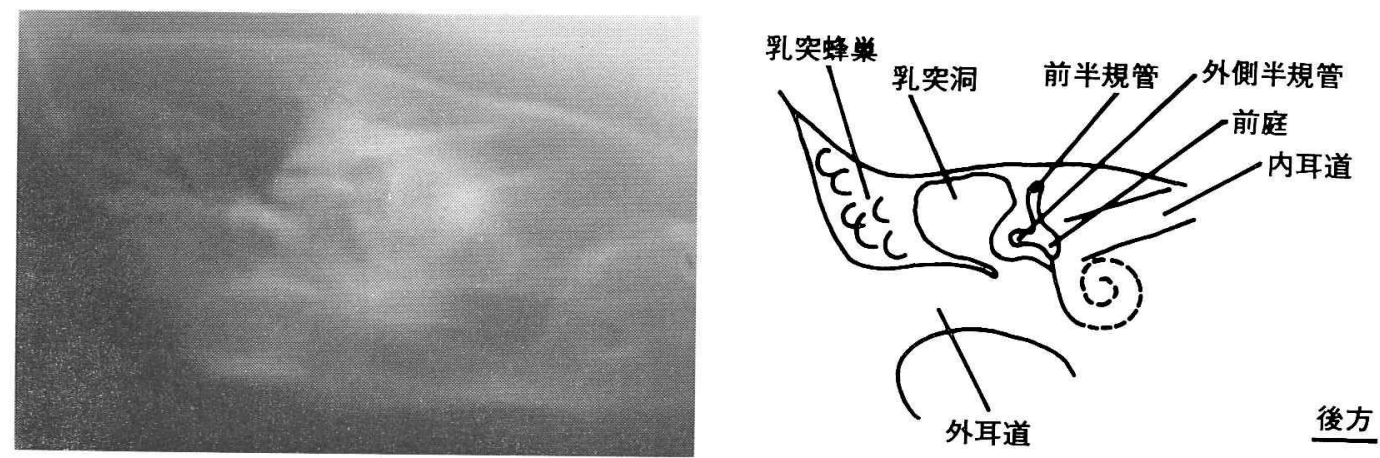

図 6 
壁, 䖮牛, 前半規管, 外側半規管, 前廷, 内耳 道が明暸であり， stapes は写らない。また顔 面神経管は水平部が写る場合むあるが，全例亡 いう訳ではない。

\section{III. 考}

1. 側頭骨断層撮影ルーチン化の条件について 我々はルーチン化という事を考えた封, 技術 者侧からの助言を屯十分に検討し, 必要最小限 の条件として次のようなものを若えた。

a . 忠者が楽な体位で撮影できること

b . 失敗をなくし作業能率を向上させるた め，位置決めが簡単にできること

c . 左右比較のため, 同一フィルムに右右の 同じ面が写るとと

d . 最大の診断情報量

e . 最小の被曝線量

以上の条件をすべて満たすべく, 屍体頭部を用 いての各種断層撮影装置を比較検討し（後述） 更に隐床例について検討を加えた結果, 光照射 により位置決めの簡単な Princeps 60 型装置 の円孤軌道を採用し，断層面は前頭面とした。

2. 被嚗線量の軽減について

まず照射野については画質を低下させる侧頭 部の体外 X 線（散乱線）を極力絞りこむ㥞, 既 製 Tubus の先端に試作の照射野可变の校
このオ法により外耳, 小耳, 内耳奇形, 小耳 真珠腫, 聴神経腫瘍等に関し診断㑛值が高いと 思われ，特に 1 枚のフィルムで左右の此較が容 易であることが冰洁の利点である。

\section{按}

り（図 3 ）を取付け, 被写体の大きさに忍じて 絞りを調節し，上下はフィルム七で $5 \mathrm{~cm}$ とし て被曝線量の滅少と共に画質の向上に努めた (図 7 ).

更に頭部に於けるX線被嚗線量で最も問題之 なる水晶体，角膜に関して，それらを想定した 両眼瞼部と後頭部に T L D 素子を添付し，前 頭 $\rightarrow$ 後頭撮影亡後頭 $\rightarrow$ 前頭撮影を行ない, 被 曝線量を測定し 画質之其に比較検討を加えた (図 8 ). その結果前頭後頭撮影では，X線管側 の左右㖷瞼部 A，Bはそれぞれ7.72R, 8.05R， フィルム側の後頭部 $\mathrm{C} 28.1 \mathrm{mR}$ であった. 次に後頭前頭撮影では，X線管侧の後頭部 $\mathrm{C}$ 9. 45R，フィルム侧の左右哏瞼部 $\mathrm{A} ， \mathrm{~B}$ はそれ ぞれ $31.5 \mathrm{mR}, 30.5 \mathrm{mR}$ であった. 测定個所で と 3 本の素子間の線量には大きな差は誌められ なかった．以上の結諭として前項 $\rightarrow$ 後頭から後 頭 $\rightarrow$ 前頭力向に曝写をかえることにより, 眼瞼 部位の被曝線量は1/200～1/300亿減少させると とが可能である，そこで我々は水晶体，角膜保

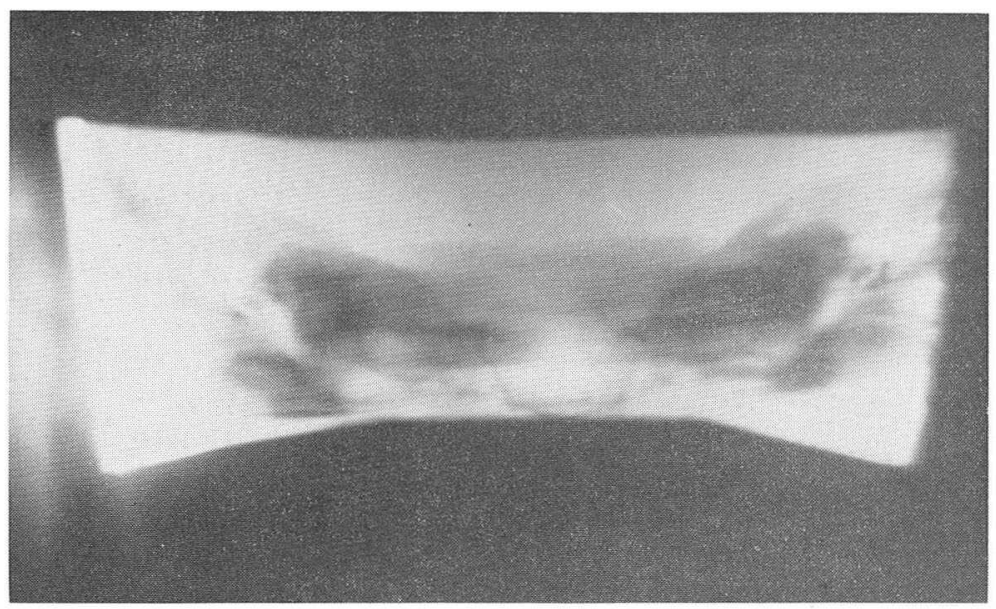




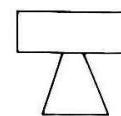

X線管

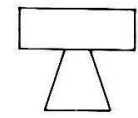

電 压: $74 \mathrm{KV}$

電 流：100mA

曝射角度：30

露出時間：約2秒
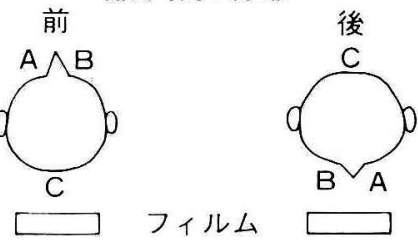
A : $\quad 7.72^{\mathrm{R}}$
$0.0315^{R}$
B :
8.05
0.0305
C :
0.0281
9. 45

図 8 熱螢光缐量計（T L D 1200型：大日本塗 料製) 各部位 3 素子による平均值：3 回 曝射量測定：神奈川県成人病センター

護の日的から郜床例では後頭前頭位で撮影する ことにした．な抬前頭後頭力向之後頭前頭方向 で得られる両者のフィルムの比較では，画質に はほとんど美が認められなかった（図 9）。

次に多層力七ッテを使用することにより，1 回の撮影で 5 枚のフィルムが撮影されるため必 然的に被嚗線量は減少する。我々は侧頭骨専用 に 3mm間隔 5 層の多層カセッテを試作し儖林に 用いている．Phantom を用いた多層増感紙の 管電厈と各層に打ける濃度差を図10に示した。
濃度差の最大值は種々異なるむ各層にお的る影 像は診断上特に支障はない。また多屏カセッテ を使用するととにより，作業時間は 1 人につき $3 \sim 5$ 分に·減少させるととが可能になった。

3 . 各種断層撮影装置の比敇検討（屍体頭部に よる)

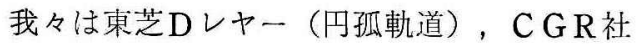
Princeps 60型（円孤軌道），東芝Cレャー (円軌道，クローバ軌道）の 3 種断層撮影装置 を用いて各軌道, 管球移動方向, 回転角度に関 して，屍体頭部による比較検討を加えた。

a . 各軌道における比較

側頭骨を刘象とした䉼層撮影に関する原則的 な理論として

1）焦点截断面間距離を大きくする

2 ）截断面フィルム間距離を小さくする

3 ）振角を小さくする $\left(60^{\circ}\right.$ 以内）

4 ）焦点の小さいX線管を使用する

の 4 つの点が一般に良い断層写真を得るための 条件である ${ }^{12)}$.

同じ円孤軌道であるDレヤーと Princeps 60 型との影像の比較では, Princeps 60型のうが 照準而フィルム問距離が短い事, 管球移動力问 が頭部に対して左右移動力向である事，更に， $1000 \mathrm{~mA}$ 装置を用いているためか，Dレヤー の $500 \mathrm{~mA}$ 装置の写真よりもコントラスト及び 鮮鋭度が其にすぐれている（図11）。

円孤軌道之円軌道方式との此較では，像の
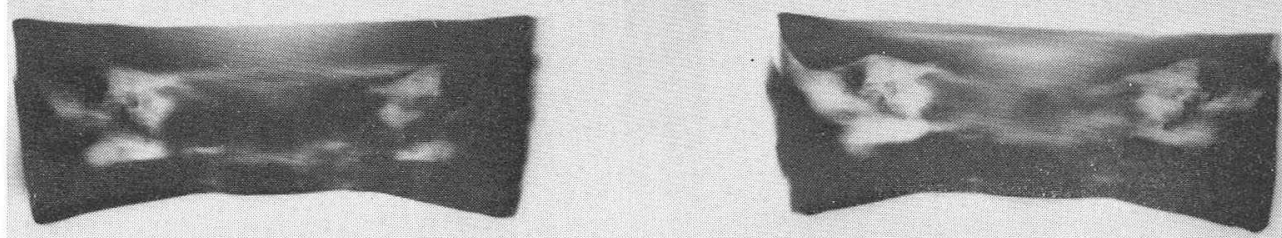

図 9 左は後頭 $\rightarrow$ 前頭方向，右は前頭 $\rightarrow$ 後頭方向 


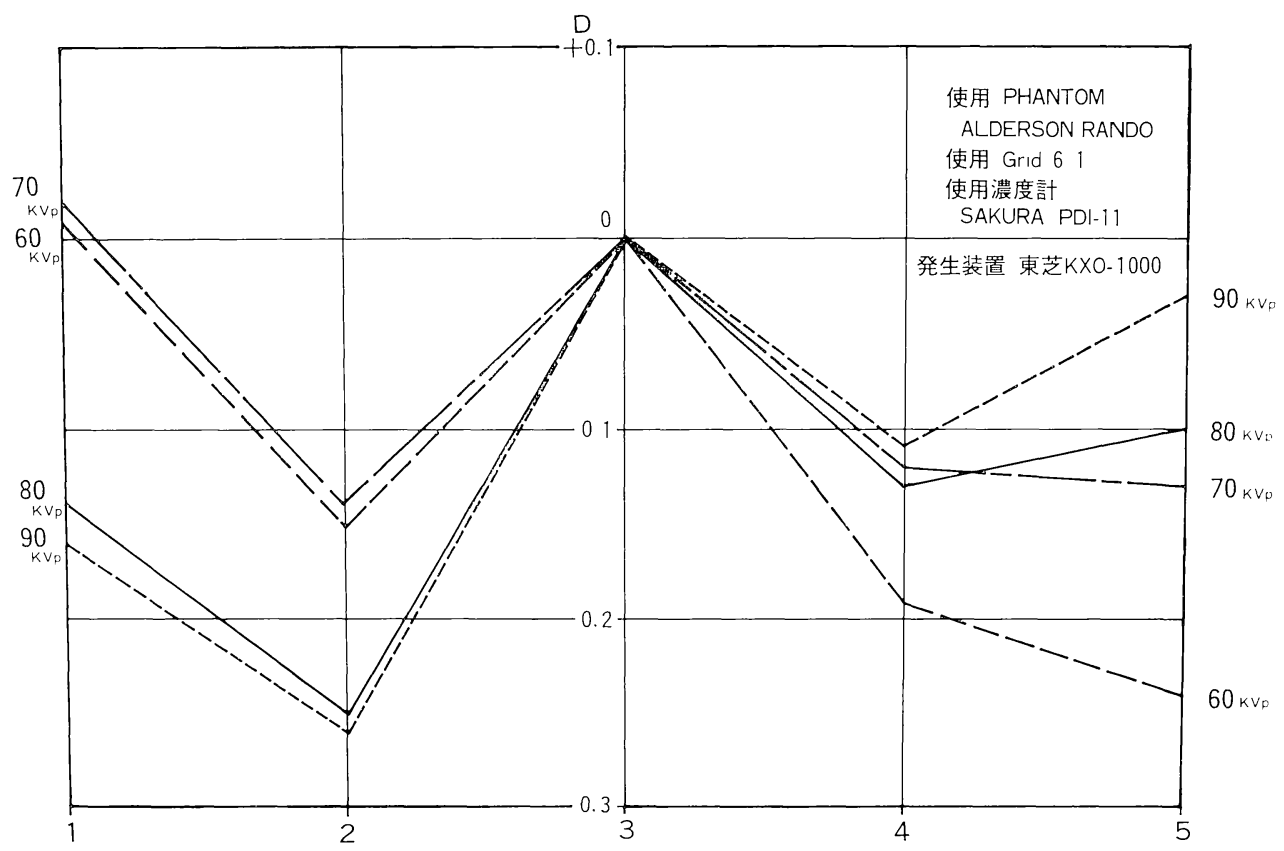

管電圧と各層の濃度差

図10

図II東芝DレヤーとPrinceps 60型との比較

\begin{tabular}{|c|c|c|}
\hline & $\mathrm{D} レ ヤ ー$ & Princeps 60型 \\
\hline 断層方式 & 円孤軌道 & 円孤軌道 \\
\hline 管球照準面間距離 & $100 \mathrm{~cm}$ & $85 \mathrm{~cm}$ \\
\hline 照準面フィルム間距離 & $30 \mathrm{~cm}$ （拡大率 1.3 倍） & 17cm（拡大率 1.2 倍） \\
\hline 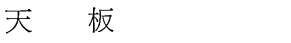 & 有（散乱線大） & 無（散乱線小） \\
\hline 散乱線除去法 & ブッキー方式 & リスホルム方式 \\
\hline 照射野絞り & 多層絞りの 1 枚羽根 & 長形試作 Tubus \\
\hline X線発生装置 & 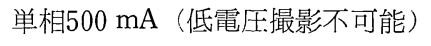 & 3 相 $1000 \mathrm{~mA}$ (低電圧撮影可能) \\
\hline
\end{tabular}

“ぼかし”の問題においては理論的に同一振角 では円軌道の方が数倍ぼかしの効果は大きくな り，断層面の薄い鮮鋭な X線像が得られる。

円軌道とクローバ軌道との比較では，円軦道 は多方向性の運動として最も簡単な運動で, 断 層面の厚さと細部の分解能を一定に保つ利点が あるも，ぼけ像が規則正しく重なるととにより 疑像を生じるのに対し，クローバ軌道は円軌道 より更に多方向性のある運動で，完全にぼかし
の効果が得られ，断層像に歪みが認められな ().

実際に各軌道におけるフィルム上での比較で は，狭軌道断層の円孤軌道断層（Dレヤ一及び Princeps 60型）と広軌道断層（円及びクロー バ断層）とでは，ぼかしの效果に执いてるか に広軌道断層がすぐれ, 円軌道とクローバ軌道 では，耳小骨及びその周辺の微細構造をよく現 出する点では, クローバ軌道の方がより診断価 
值のある情報量の多いX線像が得られることが わかった。

b ．撮影方向について

撮影方向は今までの X 線単純撮影法では, X 線中心線の入射角度の正確な決定が耳小骨を現 出する要点であり, 従って種々の位置に执いて 頭部を固定させる装置が必要であった。しかし 我々は断層撮影という点を考慮し, 解剖学的に 比較的理解しやすい前頭面と矢状面のみを使用 し，特殊な固定装置を用いなかった。

c . X線入射角度について

3 種の断層撮影装置の中で特に角度を $0^{\circ}$ 〜 $70^{\circ}$ の間で自由に変えられる Princeps 60 型を 用いた検討では，角度を大きくするに従い薄く 切れるが散乱線が多くなるためにコントラスト が悪くなる，得られた多数のフィルムによる検 討では $30^{\circ}$ が適当と考えている。 て机について は三島 ${ }^{13}$ 他多くの人々が $50^{\circ}$ が至当之報告して いるが，今後検討する問題であろう。

d 。管球移動方向之影像注ついて

東芝Dレヤーでは理論的にも尖鋭度が悪いが （図11），笑際にフィルムを用いた影像上の検 討でも管球移動方向に像の形が伸展され，耳小 骨， spur などの正確な形態を示さないため， フィルムより得られる情報量は単純写真でのむ のより少ないと考えた。佐久間 ${ }^{14)}$ は頭部断層撮 影を円孤軌道で行ない, 錘体部に関してはほと んど診断価值がないと述べている.

Princeps 60型では，前頭面に関しては像の 流れはほとんど無視でき，ルーチン化にあ成功 した。しかし矢状面については目的とする耳小 骨は写し出すととができない。これは耳小骨が 矢状面に拄いて周围の骨との間隔が狭いために 耳小骨前後の骨の陰影により重積することによ るむの之考えられる.

東芝Cレヤーでは特にクローバ軌道におい て，鮮鋭度，コントラスト共にすぐれた写真が 得られる。しかしルーチン検査としての条件で ある被曝線量, 位置決比関して，な招不十分 な点が多い。
4. 側頭骨断層撮影の臨床的意義及び将来の展 望

側頭骨断層撮影は Bartelink ${ }^{15)}$ （1932）の迷 路截断撮影の報告が始め之思われる。 その後 Kohler ${ }^{16)}$ (1937), Schutz ${ }^{17)}$ (1938), Munteau und Fink ${ }^{18)}$ (1941), Poschel (1943) Birkner $^{20)}$ (1948) , Fischgold ${ }^{21)}$ (1952), Orlandini ${ }^{22)}$ （1954）等により報告されたが， 円孤軌道装置のために診断情報量はさほど大き くなかった。最近になり Frey ${ }^{23)}$ (1956)， Mundnich ${ }^{24)}$ (1957) は hypocycloid 軌道装 置を使用して側頭骨断層撮影法を報告し Tarp ${ }^{25)}$ (1959), Brunner ${ }^{26)}$ (1961), Valvassori ${ }^{27)}$ （1961）らにより追試され，その診断は飛躍的 な進歩をとげている。

我国であ松川 ${ }^{28)}$ (1955）は円軌道の断層撮影 装置を開発し，佐久間 ${ }^{14)}$ (1958），坂倉 ${ }^{29)}$ (19 60）が側頭骨に応用し報告している。他に円孤 軌道について三島13)（1959）が，多軌道で柳原

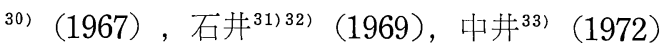
らの報告がある。しかしながら，我国において は側頭骨断層撮影は今だ一般化していないよう に思われ，特飞日常臨床のルーチン検査として 利用している施設は少ないように思われる。乙 の理由として装置の特殊性, 更に側頭骨の様な 極めて微細にして複雑な構造をむつものに対し て，1回のみの撮影で目的とする耳小骨及びそ の周图のフィルムを得ることが非常に難しいた め, 必然的に多回の撮影と長時間を要し，ひい ては被曝線量の増加をきたす事にその因がある と思われる. この欠点を除くために 1 回の被曝 で多層撮影を可能にする同時多層断層撮 影が Ziedes des Plantes ${ }^{34)}$ (1933) により考案さ れている，側頭骨に対しての同時多層断層撮影 は, 坂倉 ${ }^{29)}$, Lapayowker ${ }^{35)}$ (1962), 石井 ${ }^{31}$ ${ }^{32)}$, 中井 ${ }^{33)}$ が応用し, 実用化されている。坂倉 は円孤軌道，円軌道それぞれに，Lapayowker は円孤軌道で前頭面において $1 \mathrm{~mm}$ 間隔 4 層で 施行しており, 石井は棈円軌道で $3 \mathrm{~mm}$ 間隔 5 層 の前頭面を, 中井は hypocycloid 軌道で $1.5 \mathrm{~mm}$ 
間隔 $6 \sim 8$ 層の前頭面, 矢状面について多層力 セッテを使用している.

我々あ円孤軌道方式を用いた前頭面で $3 \mathrm{~mm}$ 間 隔 5 層の同時多層断層撮影法に成功し, 郜床で ルーチン外来 $\mathrm{X}$ 線検查として用い, 単純 $\mathrm{X}$ 線写 真では得にくい側頭骨細部の写真が得られてい る. 订孤軌道方式による側頭骨同時多層断層撮 影法は装置が一般に普及している点, 簡単な改 良で撮影できる点など極めて有意義な日常検査
法であると考えられる.

しかし手術を目的とした術前X線検査法とし ては, 前述の検討のごとく hypocycloid 軌道 (クローバ軌道) でより微細な構造を把握し， 病態をくわしく知り，計画性のある手術を行な う必要があるものと考える。それには，単に情 報量が多いというだけではなく，患者の被曝線 量, 負担，技術者の手間等十分に考慮される必 要があるのはいうまでもない事である.

\section{語}

1. Princeps 60型円孤軌道方式による $3 \mathrm{~mm}$ 間隔 5 層の同時多層断層撮影法を行ない, 日常ルー チン検査に用いている.

2. 撮影方向は被曝線量の問題から後頭前頭位で撮影する前頭面を採用した.

3．本法により通常X線単純写真で得られ難い耳小骨，上鼓室外側壁（spur），蝸牛，前半規管 外側半規管，内耳道などがほとんど失敗なく撮影するととが可能である.

4. 手術を目的とした精密検査では，鼓膜所兒，聴力検査，X線検査をいずれす詳細に検討する 必要があるが，X線検査としては，hypocycloid 軌道による微細な検討が必要であろう.

稿を終るに臨み, 御指導, 御校閲を頂いた東海大学医学部三宅浩楖教授, 並びに慶応義塾大学斎藤成司教授 に感謝いたします。

本研究に対し終始積極的に御協力いただいた川崎市立病院理学診療科諸兄に深甚なる感謝の意を表します。 本論文の要旨法日本耳鼻咽喉科学会関東地方会第 482 回, 第 485 回, 第 2 回臨床耳科学会において発表した.

\section{文献}

1) Chausse, C. : L'incidence III et la Copochirurgie. Acta Otorhinolaryngology $3: 513$, 1949.

2) Portman, G. Guillen, G. : Radiodiagnosticen Otologie. Masson et Cie, Paris, 1959.

$3)$ Samuel, E. Theron, C. : The radiology of the auditory ossicles. Brit. J. Radiol. $25: 245,1952$.

4) Welin, S. : Radiology of the temporal bone. J. Laryng. $69: 515,1955$.

5 ) Crichlow, T. V. : Discussion on mastoid radiology. J. Laryng. $69:$ 531, 1955.

6) Owen, G. R. Compere, W. E. Jr. : Radiologic examination of the temporal bone. Shambaugh, G. E. : Surgery of the ear, p. 90, Philadelphia, Saunders, 1959.

7 ) 野中康弘：耳小骨のX線学的研究，第 1 報正常耳
の耳小骨像について。日耳鼻 $65: 1343,1962$.

8 ）橋本泰彦, 他：中耳腔の $X$ 線撮影とその判読につ いて. 日耳鼻 $67: 1493,1964$.

9 ）寉田博之 : 人鼓室のレ線学的研究(1), 阪市大医誌 $9: 5481,1960$.

10）飯森堯：耳小骨のレ線学的観察. 日耳鼻 69 : 525, 1967.

11）末広恵三：耳小骨のレ線像（鐙骨を中心として） 耳鼻臨床 $60: 55,1967$.

12）綱川高美：断首撮影の理論之技術，結核子防会. 1965.

13）三島則美：聴器の断層レ線学的研究. 日耳鼻62： 2505, 1959.

14）佐久間寛：円軌道移動方式断層撮影法の研究（第 20報)。日医放 18：66，1958。

15) Bartelink, D. L. : Röntgenschnitte. Fortschr. Röntgenstr. $47:$ 399, 1933. 
16) Kohler, A. : Fortschr. Röntgenstr. $56: 60$, 1937.

17) Schutz, W. : Röntgenschichtaufnahmen des normalen Wartzenvorsatzes und der Felsenbeinpyramide. Z. Hals-Nas-Ohr. HK. 43 : 435, 1938.

18) Munteau, E. und Fx ink, J. : Das Röntgenogram des Felsenbeines. Fort-schr. Röntgenstr. $63: 183,1941$.

19) Poschel, M.:Der tomographische Querschnitt durch das Felsenbein. Fortschr. Röntgenstr. 63 : 174, 1943.

20) Birkner, R. : Der tomographische Horisontalschnitt des Felsenbeines. Fortschr.

Röntgenstr. 7I : 349, 1949.

21) Fischgold, M., David, M. und Rergeat, P. : Masson, Paris, 1952.

22) Orlandini, L., et Rabaiotti, A. : Arch. Ital. Otol. $65: 203$, 1954.

23) Frey, K. W. : Schichtaufnahmen des Felsenbeunes mit polyzyklischer Ver-wischnung. Fortschr. Geb. Röntgenstrahlen. 85 : 433, 1956.

24) Mundnich, K, und Frey, K.W. : Das Röntgenschichtbild des Ohres. Stuttgart, Georg Thieme Verlag, 1959.

25) Tarp, O.: Tomography of the temporal bone with polytome. Acta Radiol. 51:105 116, 1959.

26) Brunner, S., Petersen, O., and Stoksted,
P. : Tomography of auditory ossicles. Acta Radiol. $56: 20 \sim 29,1961$.

27) Valvassori, G. E. : Laminography of the ear: Normal roentgenographic anatomy. Am. J. Roentgenol. $89: 1168 \sim, 1963$.

28）松川明, 他：円軌道移動方式断層撮影の跨究第 1 報撮影装置について。日医放Ｉ5：549，1955.

29）坂倉幹：耳鼻科領域における同時多層撮影の基礎 的研究. 耳鼻臨床 $53: 711,1960$.

30) 柳原尚明, 他：聴神経腫瘍のレ線学的診断 I. 内 耳道断層撮影. 耳鼻臨床 60 : 1076, 1967.

31）石井哲夫，他：側頭骨における Multidirectional Tomography に関する研究. I. 先天性外 耳道閉鎖症. 耳喉 41：573，1969.

32）石井哲夫，他：側頭骨の多軌道断層撮影. II. 内 耳奇形. Audiology Jap. I6 : 25, 1973.

33）中井義明, 他：側頭骨における断層撮影. 耳鼻臨床 65：547, 1972.

34) Ziedes des Plantes, B. G. : A new method of differentiation in roentgenography (Planigraphy.) Acta Radiol. 13 : 182, 1932.

35) Lapayowker, M. S., Ronis, M. L., Woloshin, H. J. : The use of plesiosectional tomography in otology. The Laryngoscope LXXV : 1837 1846, 1965.

原稿到着：昭和52年11月10日 別刷請求先 : 新川敦 荳259-11神奈川県伊勢原市望星台 東海大学医学部耳鼻咽喉科学教室 